JURNAL ILMIAH ELEKTRONIKA DAN KOMPUTER, Vol.13, No.1, Juli 2020, pp. 87 - 102

p-ISSN : 1907-0012 (print)

e-ISSN : 2714-5417 (online)

http://journal.stekom.ac.id/index.php/elkom

- page 87

\title{
Penggunaan Sensor TCS3200 dan NodeMCU untuk Mendeteksi Warna Daun Padi dalam Menentukan Jumlah Pupuk Urea Bebasis IoT
}

\author{
Dani Sasmoko ${ }^{1}$, Danang Danang ${ }^{2}$, Padjar Setyo Budi ${ }^{3}$ dan Muhammad Agus Kurniawan ${ }^{4}$ \\ ${ }^{1}$ Manajemen Infromatika, Universitas STEKOM, ${ }^{2}$ Teknik Elektro, Universitas STEKOM , $3,{ }^{4}$ Sistem \\ Komputer ,Universitas STEKOM .Jl. Majapahit 605, Semarang \\ E-mail : dani@stekom.ac.id ${ }^{1}$, danang@,stekom.ac.id ${ }^{2}$, \\ padjar@stekom.ac.id ${ }^{3}$, kurniawantsr1@.gmail.com $^{4}$
}

ARTICLE INFO

Article history:

Received 30 Mei 2020

Received in revised form 2 Juni 2020

Accepted 10 Juni 2020

Available online 12 Juni 2020
ABSTRACT

Technological developments encourage changes in the way decisions are made. In terms of stopping the application of urea fertilizer, farmers still rely on BWD observations. In this study, using the RnD method by directly observing the research location in the farmer group Gapoktan, in the village of Tosari, Kendan district and analyzing the problem then making a prototype which will be tested by experts. In this study, a tool was made using NodeMCU with TCS3200 sensor to detect color, which was then sent via the internet to the database using IoT technology. In this study, using several trials with different parameters of urea fertilizer use and the results of the TCS3200 sensor can detect colors according to what is on the BWD and send data to the database via the internet. In this system, farmers can recommend the use of suitable urea fertilizers outside a certain area so as to minimize errors in the observation on BWD, this will make the use of urea fertilizer to be the right dose..

Keywords: color_leaf; nodemcu; tcs3200; IoT; urea

\section{Introduction}

Didalam pertanian untuk menunjang hasil panen yang maksimal. Ada beberapa faktor yang perlu diperhatikan, khususnya faktor pemberian dosis pupuk tanaman padi. Untuk meningkatkan hasil dan mutu beras, tanaman padi memerlukan unsur hara dalam jumlah banyak (makro) diantaranya nitrogen (N), fosfor $(\mathrm{P})$, kalium $(\mathrm{K})$ dan belerang $(\mathrm{S})$. Selain itu, diperlukan unsur yang jumlahnya sangat sedikit (mikro) seperti seng $(\mathrm{Zn})$, tembaga $(\mathrm{Cu})$, besi $(\mathrm{Fe})$, molibdenum $(\mathrm{Mo})$, boron $(\mathrm{B})$, dan mangan $(\mathrm{Mn})[1]$.

Tanaman yang kekurangan nitrogen $(\mathrm{N})$ tumbuhnya kerdil, anakan sedikit dan daunnya berwarna kuning pucat, terutama daun tua. Sebaliknya, tanaman yang dipupuk urea (unsur N) berlebihan tumbuhnya subur, daun hijau tua, anakan banyak, jumlah malai banyak tetapi tanaman mudah rebah dan pemasakan gabah lambat. Tanaman yang kekurangan unsur hara fosfor $(\mathrm{P})$ tumbuhnya kerdil, daun sempit berwarna hijau tua, anakan sedikit, pemasakan lambat dan kehampaan gabah tinggi[2]. Sedangkan tanaman yang kekurangan kalium $(\mathrm{K})$, batangnya lemah, daun terkulai dan cepat menua, mudah terserang hama dan penyakit, mudah rebah, persentase gabah hamanya tinggi, butir hijau banyak dan mutu beras rendah.

Penggunaan bagan warna daun untuk menentukan dosis kebutuhan pupuk nitrogen dilakukan 25 (HST). Di Kelompok Tani Gapoktan Desa Tosari, kecamatan brangsong kabupaten kendal belum sepenuhnya memanfaatkan bagan warna daun (BWD) oleh para petani. Hal ini disebabkan karena sebagian besar petani padi sulit menentukan tingkat kehijauan warna daun padi yang sesuai dengan warna hijau yang terdapat pada bagan warna daun. Petugas pertanian Kecamatan hanya melakukan pengecekkan menggunakan bagan warna daun (BWD) terhadap tanaman padi petani hanya mengambil sampel per Desa dalam satu Kecamatan. Oleh sebab itu, perlu dibuatkan sistem yang dapat menentukan tingkat kehijauan

Received Mei 23, 2020; Revised Juni 29, 2020; Accepted Juli 12, 2020 
warna daun padi secara spesifik dan sesuai dengan skala warna pada bagan warna daun[3]. Sistem yang akan dibuat harus dirancang dalam bentuk yang mudah digunakan dan tidak menimbulkan kebingungan bagi para petani.

Tabel 1 Perbandingan hasil panen penggunaan pupuk Nitrogen di Desa Tosari pada masa tanam April 2019 - September 2019.

\begin{tabular}{|c|c|c|}
\hline Sampel & $\begin{array}{l}\text { Penggunaan Dosis } \\
\text { Pupuk N }\end{array}$ & $\begin{array}{l}\text { Hasil Panen } \\
\text { Rata-rata } \\
\text { Ton/Ha }\end{array}$ \\
\hline $\begin{array}{l}\text { Sampel } \\
\text { lahan A }\end{array}$ & Rendah & 7,6 \\
\hline $\begin{array}{l}\text { Sampel } \\
\text { lahan B }\end{array}$ & Sedang & 7,8 \\
\hline $\begin{array}{l}\text { Sampel } \\
\text { lahan C }\end{array}$ & Tinggi & 8 \\
\hline
\end{tabular}

Pada tabel 1 dapat di ketahui perbandingan penggunaan pupuk berpengaruh terhadap jumlah panen rata-rata. Selain itu Berdasarkan pengamatan langsung, belum adanya sistem di Kabupaten Kendal apalagi, di Kelompok Tani Gapoktan Desa Tosari yang memanfaatkan teknologi mikrokontroler sebagai sarana untuk memudahkan dalam menentukan kadar kebutuhan pupuk Nitrogen untuk tanaman padi. Dengan adanya sistem ini petani akan dipermudah dalam menentukan kadar Nitrogen yang diperlukan untuk pemupukan padi pada setiap sawah, mengefisienkan jumlah pupuk yang diperlukan untuk sekali pemupukan dilihat dari tingkat kesuburan padi berdasarkan warna daun pada setiap sawah. Selain itu, sistem ini juga akan mampu memberikan kemudahan bagi petugas dari Dinas Pertanian dalam memberikan bimbingan kepada petani mengenai aturan pemberian pupuk nitrogen yang baik dan benar untuk pemupukan padi.

Pada tabel 2 adalah tabel dosis pemberian pupuk nitrogen berdasarkan Bagan Warna Daun (BWD) saat pemupukan 25-35 hari setelah tanam (hst) dengan target Produksi 8-12 ton / Ha:

Tabel 2 Dosis pemberian pupuk nitrogen berdasarkan Bagan Warna Daun

\begin{tabular}{|c|c|c|}
\hline $\begin{array}{l}\text { Skala Warna } \\
\text { BWD }\end{array}$ & $\begin{array}{l}\text { Nilai Pembacaan } \\
\text { Warna BWD } \\
\leq 1\end{array}$ & $\begin{array}{l}\text { Rekomendasi Takaran } \\
\text { Pupuk Urea (Kg / Ha) } \\
175-200\end{array}$ \\
\hline N & 2 & 175 \\
\hline$\omega$ & 3 & 150 \\
\hline+ & 4 & 125 \\
\hline ir & 5 & 100 \\
\hline$\sigma$ & 6 & 75 \\
\hline 8 & 7 & 50 \\
\hline$\infty$ & $\geq 8$ & $0-50$ \\
\hline
\end{tabular}

Pada tabel 3 adalah Indikator warna BWD yang digunakan peneliti yaitu terdiri dari empat warna sesuai petunjuk BWD IRRI.

Tabel 3. Dosis pemberian pupuk nitrogen berdasarkan Bagan Warna Daun Untuk E-BWD

\begin{tabular}{lll}
\hline Skala Warna & Nilai Pembacaan & Rekomendasi Takaran \\
BWD & Warna BWD & Pupuk Urea (Kg / Ha)
\end{tabular}

125

JURNAL ILMIAH ELEKTRONIKA DAN KOMPUTER Vol. 13, No. 1, Juli 2020: 87 - 102 


\begin{tabular}{lll}
\hline 3 & 100 \\
4 & 75 \\
5 & 50 \\
\hline
\end{tabular}

Pada penelitian ini menggunaan sensor warna yang terhubung mikrokontroler NodeMCU.Penggunaan teknologi mikrokontroler yang dapat mengontrol ataupun mengirim data melalui modul yang secara langsung menghasilkan output yang datanya akan diterima oleh server ataupun ditampilkan secara langsung[4]. Salah satu modul tersebut adalah sensor TCS 3200 yang dapat digunakan untuk medeteksi suatu objek benda ataupun warna yang dimonitor[5].

Modul sensor ini dalam pengiriman datanya dapat dipadukan dengan teknologi wireless. Dengan teknologi wireless, data ataupun informasi yang diterima mampu dilihat secara daring oleh user. Dengan menggunakan gawainya, user tidak perlu menggunakan kabel dalam mengirim maupun menerima informasi. Informasi yang diperoleh dapat secara realtime diakses melalui gawai (free space)[6][7].

Berdasarkan uraian diatas, maka pada tugas akhir ini akan dibuat penelitian Penggunaan Sensor TCS3200 dan NodeMCU untuk mendeteksi warna daun padi dalam menentukan jumlah pupuk urea.

Diharapkan dengan adanya sistem ini para petani dapat terbantu dalam penentuan dosis pupuk Nitrogen tanaman padinya, melalui peyimpanan data dosis masing-masing lahan. Memudahkan pemerintah dalam pemetaan jumlah subsidi pupuk Nitrogen untuk petani.Dengan adanya sistem daring petani dapat mengakses berapa dosis pupuk tanaman padi mereka secara realtime. Diharapkan nantinya satu-persatu petani dapat mempunyai alat ini, untuk menentukan dosis pupuk Nitrogen mereka. Ketua kelompok akan memberikan pengetahuan tentang tata cara penggunaan alat ini kepada setiap anggota kelompot tani.

\section{METODE PENELITIAN}

Dalam penelitian ini penulis menggunakan prosedur pengembangan Research and Development yaitu metode penelitian yang digunakan untuk menghasilkan produk, dan menguji keefektifan produk tersebut, penulis akan menggunakan 6 tahapan metode R\&D Menurut Borg and, yaitu:

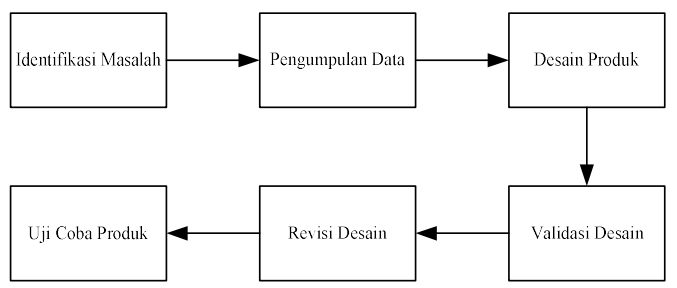

Gambar 1.Enam Langkah penggunaan MetodeResearchand Development (R\&D)

Pada penelitian ini penulis menggunakan 6 prosedur pengembangan Research and Development dari teori Bord and Gall[8], yaitu:

\section{a. Identifikasi Masalah}

Penelitian dapat berangkat dari adanya potensi atau masalah. Kelompok Tani Gapoktan Desa Tosari merupakan gabungan dari tiga kelompok tani desa Tosari. Luas lahan pertanian mencapai 106 hektar. Dan hampir setiap tahun sebagian besar lahan pertaniannya ditanami padi dan ternyata mempunyai beberapa masalah antara lain yang di bahas penelitian ini adalah penggunaan bagan warna dalam menentukan pupuk masih menggunakan pengamatan secara langsung dan belum ada nya dokumentasi data.

\section{b. Pengumpulan data (Research and Information)}

1. Data Primer yaitu data yang berasal dari obyek penelitian yang meliputi:

a) Observasi

\section{Rancang Bangun Sistem Informasi Penjualan Online Berbasis Webmobile}


Pengamatan secara langsung terhadap objek yang dijadikan sebagai penelitian. Dari hasil observasi dilakukan langsung kelahan pertanian dikelompok tani Gapoktan desa Tosari didapatkan data berupa, proses pemberian pupuk Nitrogen masih menggunakan takaran perkiraan dan pengetahuan mengenai petunjuk pemakaian BWD masih sangat rendah.

b) wawancara yaitu dengan melakukan tanya jawab atau konsultasi yang dilakukan dengan secara langsung dengan Ketua dan petani di Kelompok Tani Gapoktan Desa Tosari Kendal mengenai informasi-informasi yang berhubungan dengan penelitian.

2. Data Sekunder yaitu data yang berasal dari luar obyek penelitian yang meliputi : pengumpulan buku dan literatur yang berkaitan dengan obyek penelitian. Buku tentang pemakaian Bagan Warna Daun dan jurnal-jurnal berkaitan dengan sistem yang akan dibuat oleh peneliti.

\section{c. Desain Produk (Develop preliminary form of product)}

Pada penelitian ini di gunakan frizing untuk membuat skema alat dan menggunakan, flow cart untuk menjelaskan alur jalan nya alat yang digunakan serta UML untuk merancang alur jalan nya software.

\section{d. Perbaikan Desain (Main Product Revision)}

Setelah desain produk, divalidasi dan dinilai oleh dan para ahli lainnya, maka akan dapat diketahui kelemahannya. Peneliti mencari kekurangan dan kelemahan yang ada pada produknya. Setelah didapat kelemahan pada produknya, menganalisa apa yang menjadi kelemahan. Pada kelemahan tersebut selanjutnya peneliti mencoba untuk mengurangi kelemahan dengan cara memperbaiki desain.

\section{e. Uji Coba Produk (Main Field Testing)}

Dalam hal ini, desain produk dapat langsung diuji coba, setelah validasi dan revisi. Uji coba produk tahap awal dilakukan dengan simulasi menggunakan sistem tersebut. Setelah disimulasikan, maka dapat diuji cobakan pada daun tanaman padi di Kelompok Tani Gapoktan Desa Tosari.

\section{Metode Pengembangan Sistem}

\section{Alur jalan nya Penelitian.}

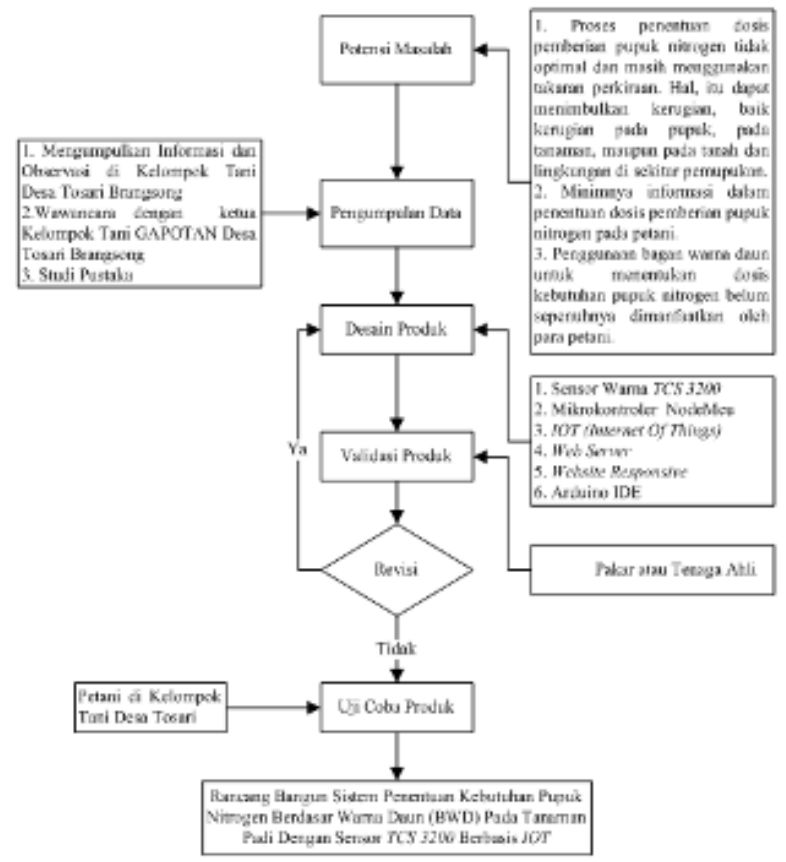

Gambar 2.Alur jalan nya Penelitian

JURNAL ILMIAH ELEKTRONIKA DAN KOMPUTER Vol. 13, No. 1, Juli $2020: 87$ - 102 
Keterangan:

1. Penulis mengidentifikasi masalah, dan merumuskan masalah yang ada pada kelompok Tani desa Tosari.

2. Selanjutnya penulis melakukan pengumpulan data untuk mencari dan melengkapi informasi yang dibutuhkan dalam pembuatan produk melalui wawancara dan study kelompok Tani desa Tosari yang berkaitan dengan permasalahan yang dikaji untuk menentukan konsep-konsep yang memperkuat produk yang akan di hasilkan melalui sumber-sumber,antara lain buku,jurnal dan internet.

3. Mendesain dan merancang produk menggunakan NodeMcu, sensor TCS 3200, MySQL, Webserver, Sublime, dan Arduino IDE.

4. Dalam tahap ini penulis melakukan uji coba dengan pakar atau tenaga ahli untuk menguji produk menggunakan kuesioner atau angket.

5. Pada produk revisi produk merupakan langkah perbaikan atau penyermpurnaan dari hasil evaluasi

6. Uji efektivitas produk yang melibatkan pengguna yaitu petani dikelompok tani desa Tosari.

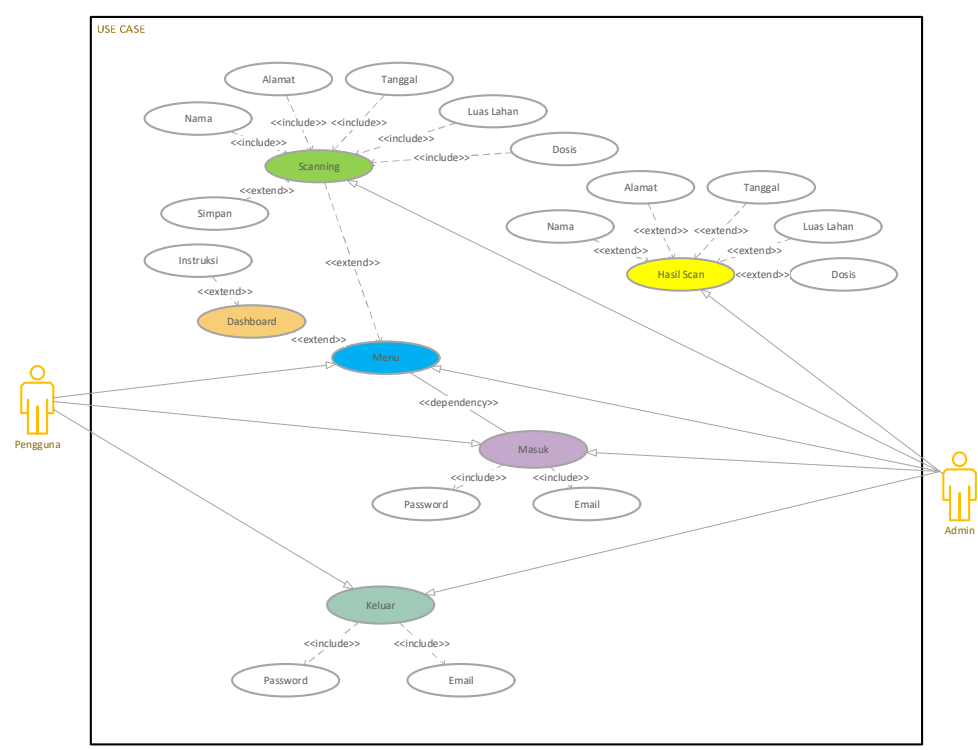

Gambar 3. Uses Case Diagram Sistem Sekarang

Dari bagan UML di atas untuk menggambarkan proses yang terjadi padasistem yang di kembangkan agar memudah kan pemodelan aplikasi E-BWD yang di buat[9] .

Keterangan Use Case pada UML penentuan Dosis kebutuhan pupuk Nitrogen :

1. Proses Login atau MasukPengguna berinteraksi dengan aplikasi melalui interface halaman login dan halaman menu, dimana halaman login menjadi dependency bagi halaman menu. Hal ini membuat halaman menu hanya bisa diakses setelah syarat-syarat pada halaman login terpenuhi, yaitu kesesuaian email dan password yang diberikan pengguna dengan data yang tersimpan di MySQL. Status login pengguna ini tetap tersimpan sampai pengguna melakukan perintah menu logOut.

2. Setelah halaman login berhasil melakukan validasi dan autentikasi, maka pengguna dapat mengakses halaman menu yang otomatis terbuka setelah login berhasil. Pada halaman menu Scanning, menu ini merupakan scanning untuk mendeteksi jumlah dosis kebutuhan pupuk Nitrogen. Sebelum melakukan Scan daun padi, pengguna harus mengisi data pada Form Proses Scanning dengan lengkap setelah data lengkap maka pengguna cukup menekan tombol simpan untuk mengaktifkan NodeMcu.

3. Setelah melakukan proses Scanning maka pengguana dapat melihat hasil dari proses Scanning pada tampilan menu Hasil Scan.

Rancang Bangun Sistem Informasi Penjualan Online Berbasis Webmobile 
LCD (Liquid Cristal Display)

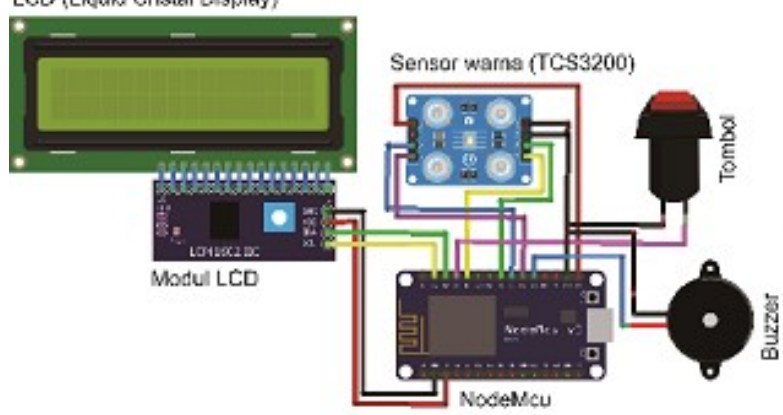

Gambar 4. Skematik Alat yg di kembangkan

Keterangan skematik dari rangkaian elektronik :

1. NodeMcu Sebagai pengendali atau kontroler dari keseluruhan sistem yang nanti nya akan terhubung ke internet dari smarphone yang nanti akan di input data pengguna yang berbasis Internet Of Things dimana data warna akan di kirim dari NodeMCU ke database melalui Internet.[10]

2. Sensor TCS 3200 untuk mendeteksi warna daun padi yang parameter warna nya sudah di atur sesuai warna pada BWD sehingga nanti sensor akan sama mendeteksi warna nya[11]

3. LCD sebagai penampil data sensor, dan status proses.

4. Push Button sebagai perintah untuk proses Scan dari sampel satu sampai 5.

5. Buzzer sebagai penanda proses Scan pada sampel selesai.

\section{Implementasi Perancangan Sistem}

\section{Tampilan Form Login}

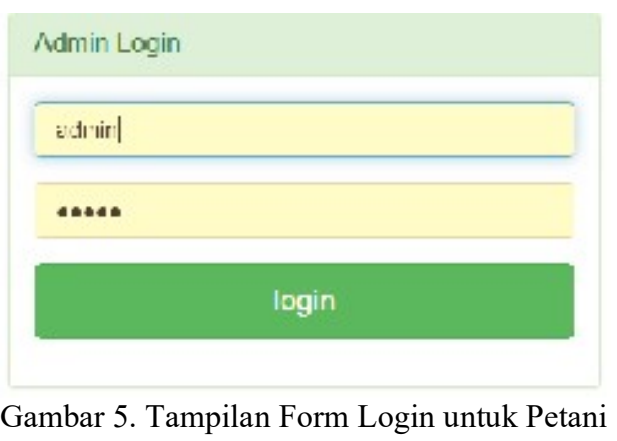

Ini adalah tampilan dari Form login pada sistem penentuan pupuk Nitrogen untuk Petani sebelum melakukan ataupun melihat data hasil Scanning mereka.

\section{Tampilan Dashboard}

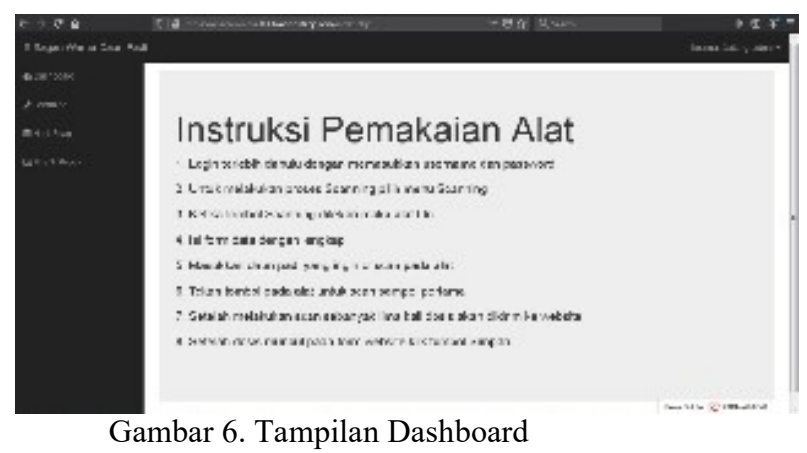

JURNAL ILMIAH ELEKTRONIKA DAN KOMPUTER Vol. 13, No. 1, Juli 2020 : 87 - 102 
Tampilan ini berisi tentang intruksi pemakaian alat dari pertama login sampai proses penyimpanan data oleh petani.

\section{Tampilan Menu Scanning}

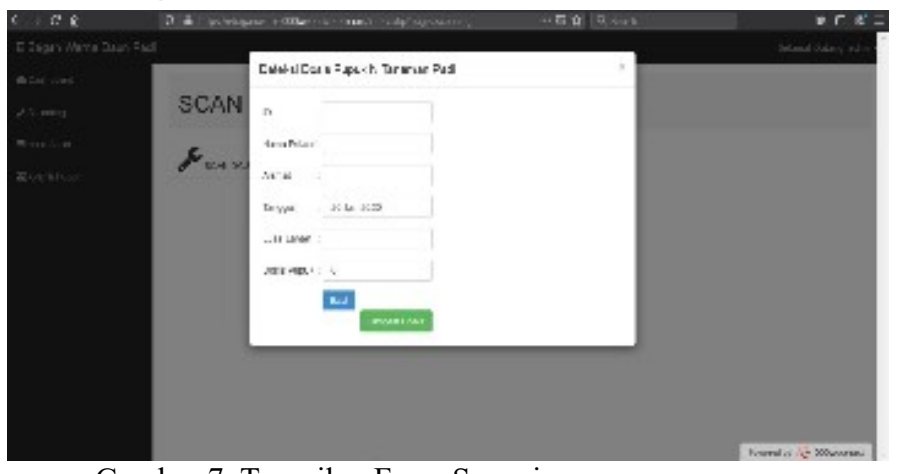

Gambar 7. Tampilan Form Scanning

Tampilan scanning untuk mendeteksi jumlah dosis kebutuhan pupuk Nitrogen. User memilih menu scan dan tombol scan untuk mengaktifkan alat. Setelah mengisi kolom Id, Nama, Alamat dan Luas Lahan form maka data dosis akan muncul kolom dosis. Pilih simpan untuk menyimpan dosis.

1. Kolom Id diisi dengan Nomor anggota kelompok tani atau Nomor KTP yang telah terdaftar.

2. Kolom Nama Pengguna diisi Nama lengkap Pengguna

3. Kolom Alamat Petani diisi Alamat lengkap Pengguna

4. Tanggal akan otomatis muncul pada kolom sesuai tanggal dimana pengguna melakukan proses scanning

5. Kolom Luas Lahan diisi berapa luas lahan pengguna

6. Kolom Dosis Pupuk akan muncul setelah pengguna selesai melakukan proses scan

Tampilan Tabel Hasil Scan

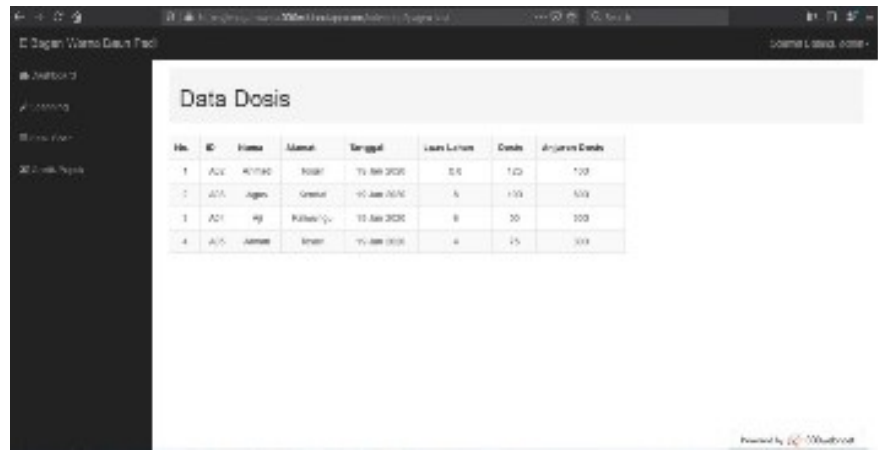

Gambar 8. Tampilan Form Scanning

Tampilan menu tabel hasil scan merupakan tampilan dimana hasil dari beberapa data dari proses Scanning. Tampilan ini berisi tentang tabel data berupa ID,Nama, Alamat, Tanggal, Luas lahan dan Dosis.

1. Kolom ID berisi No anggota kelompok Tani pengguna yang telah dimasukkan melalui form data

2. Kolom Nama berisi Nama lengkap dari pengguna atau anggota kelompok tani

3. Kolom Tanggal berisi Tanggal proses penentuan dosis dengan E-BWD

4. Kolom Luas lahan berisi luas lahan dari pengguna atau anggota kelompot tani

5. Kolom Dosis berisi Dosis yang dikeluarkan alat sesuai warna daun dan nilai RGB daun.

6. Kolom Dosis Anjuran berisi hasil dosis dikalikan luas lahan dosis anjuran adalah dosis yang dianjurkan oleh sistem untuk petani. 
Tampilan Grafik Hasil Scan

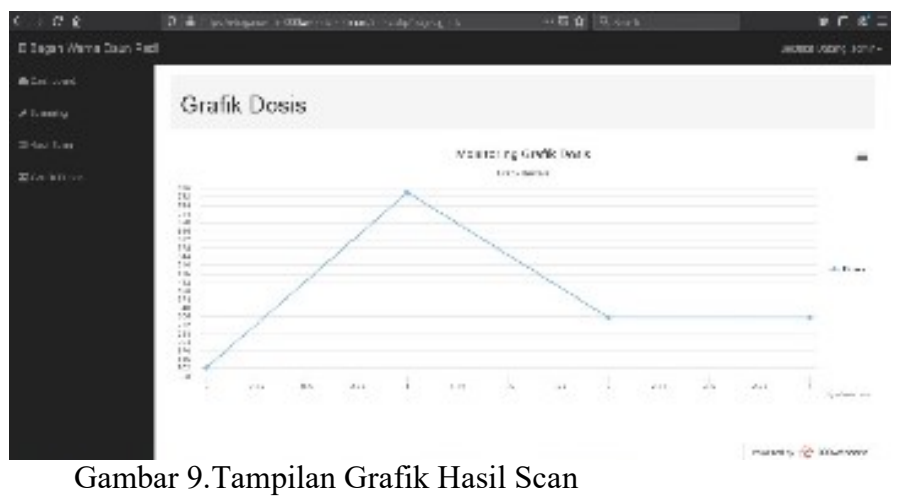

Tampilan menu Grafik merupakan tampilan Grafik data dosis pengguna berdasar id, digunakan untuk mempermudah user melihat data dosis selain melihat dari tabel.Dari grafik ini petugas ataupun ketua Kelompok Tani dapat memantau berapa jumlah pupuk yang dikeluarkan anggotanya untuk pemupukkan lahan padi mereka. Sehingga proses pemetaan ataupun pemberian jumlah subsidi pupuk bisa lebih mudah.

\section{Pengaktifan alat}

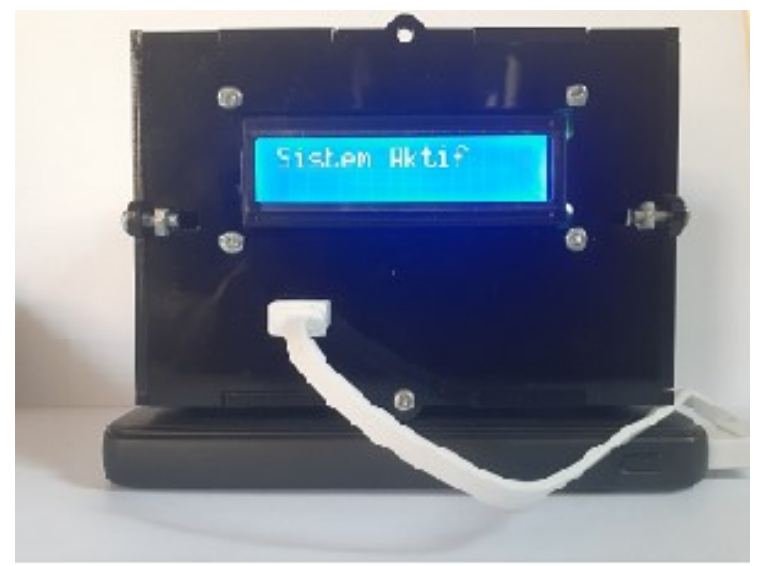

Gambar 10. Tampilan alat telah aktif

Setelah setelah wifi tersambung maka akan muncul tulisan berupa "Sistem aktif" pada LCD. Sebelum pengguna melakukan proses scanning pada alat, pengguna harus mengaktifkan tombol scan pada menu scanning pada website. Setelah pengguna mengaktifkan alat pengguna dapat melakukan proses scanning dengan menekan tombol yang ada diatas alat. Dengan menekan tombol pertama untuk melakukan proses scanning pengguna menunggu indikator buzzer berbunyi untuk melakukan proses scanning berikutnya sampai dengan lima kali proses scanning, setelah melakukan proses lima kali proses scanning maka nilai dosis akan muncul sesuai nilai RGB sesuai kalibrasi daun[12].

\section{Pengujian dengan sampel daun padi sesuai indikator 2 BWD}

1. Pengujian pada sampel daun indikator 2 BWD dengan alat E-BWD

Pada pengujian dengan daun padi yang mempunyai warna yang sama dengan warna indikator nomor 2 BWD menunjukkan hasil RGB dengan rata-rata diatas sesuai Indikator 2 Kalibrasi. Sebelumnya peneliti membuat range untuk membatasi nilai minimum dan nilai maksimal RGB. Nilai RGB itulah yang menjadi patokan dari berapa jumlah dosis yang akan keluar pada LCD maupun Website[3].

JURNAL ILMIAH ELEKTRONIKA DAN KOMPUTER Vol. 13, No. 1, Juli 2020 : 87 - 102 


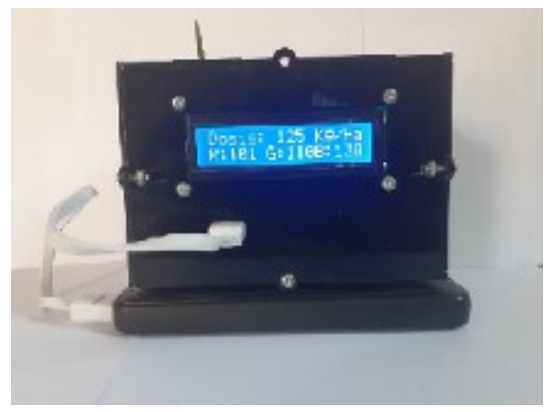

Gambar 11 Tampil Dosis dan RGB pada LCD indikator 2 BWD

Dilihat pada gambar diatas menunjukkan nilai RGB dari rata-rata setelah lima kali melakukan proses scanning. Dari setiap melakukan proses scanning, alat akan menampilkan nilai RGB dari daun tersebut.

2. Pengujian pada sampel daun indikator 2 BWD dengan alat E-BWD

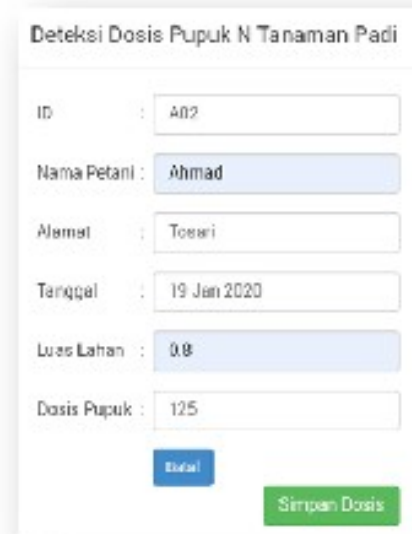

Gambar 12. Tampil Dosis pada Website indikator 2 BWD

Setelah melakukan proses scanning dan mengisi data pada form maka nilai dosis akan muncul $125 \mathrm{Kg} / \mathrm{Ha}$ sesuai nilai dosis yang telah di tetapkan oleh kementrian pertanian. Dan pengguna dapat menyimpannya dengan menekan tombol simpan.

3. Pengujian pada sampel daun indikator 2 BWD dengan alat E-BWD

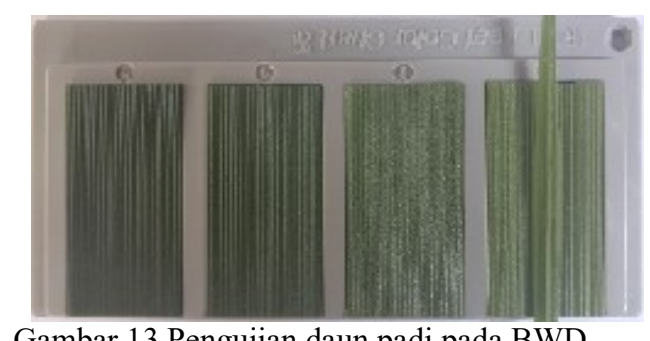

Gambar 13 Pengujian daun padi pada BWD

Gambar diatas menunjukkan berupa warna daun padi sesuai warna BWD dengan indikator nomor dua. Dan dosis BWD sama dengan dosis yang dikeluarkan oleh E-BWD yaitu $125 \mathrm{Kg} / \mathrm{Ha}$

Pengujian dengan sampel daun padi sesuai indikator 3 BWD

1. Pengujian pada sampel daun indikator 3 BWD dengan alat E-BWD

Rancang Bangun Sistem Informasi Penjualan Online Berbasis Webmobile 


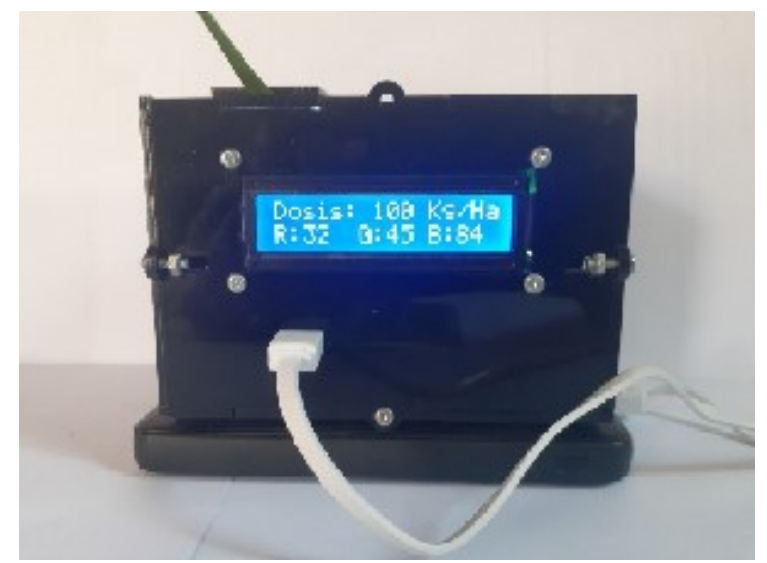

Gambar 14.Tampil Dosis dan RGB pada LCD indikator 3

Pada pengujian dengan daun padi yang mempunyai warna yang sama dengan warna indikator nomor 3 BWD menunjukkan hasil RGB dengan rata-rata diatas sesuai Indikator 3 Kalibrasi. Sebelumnya peneliti membuat range untuk membatasi nilai minimum dan nilai maksimal RGB. Nilai RGB itulah yang menjadi patokan dari berapa jumlah dosis yang akan keluar pada LCD maupun Website

2. Pengujian pada sampel daun indikator 3 BWD dengan alat E-BWD

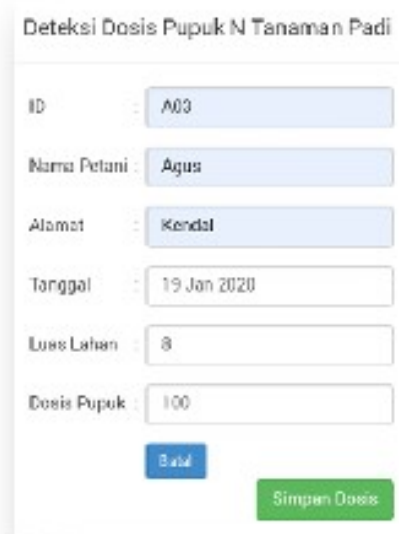

Gambar 14. Tampil Dosis pada Website indikator 3

Setelah melakukan proses scanning dan mengisi data pada form maka nilai dosis akan muncul $100 \mathrm{Kg} / \mathrm{Ha}$ sesuai nilai dosis yang telah di tetapkan oleh kementrian pertanian. Dan pengguna dapat menyimpannya dengan menekan tombol simpan.

3. Pengujian pada sampel daun indikator 3 BWD dengan alat E-BWD

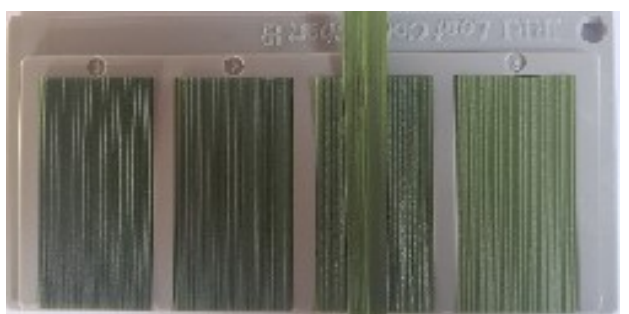

Gambar 15.Pengujian daun padi pada BWD

JURNAL ILMIAH ELEKTRONIKA DAN KOMPUTER Vol. 13, No. 1, Juli $2020: 87$ - 102 
Gambar diatas menunjukkan berupa warna daun padi sesuai warna BWD dengan indikator nomor dua. Dan dosis BWD sama dengan dosis yang dikeluarkan oleh E-BWD yaitu $100 \mathrm{Kg} / \mathrm{Ha}$

\section{Pengujian pada sampel daun indikator 4 BWD dengan alat E-BWD}

1. Pengujian pada sampel daun indikator 4 BWD dengan alat E-BWD

Pada pengujian dengan daun padi yang mempunyai warna yang sama dengan warna indikator nomor 4 BWD menunjukkan hasil RGB dengan rata-rata diatas sesuai Indikator 4 Kalibrasi. Sebelumnya peneliti membuat range untuk membatasi nilai minimum dan nilai maksimal RGB. Nilai RGB itulah yang menjadi patokan dari berapa jumlah dosis yang akan keluar pada LCD maupun Website.

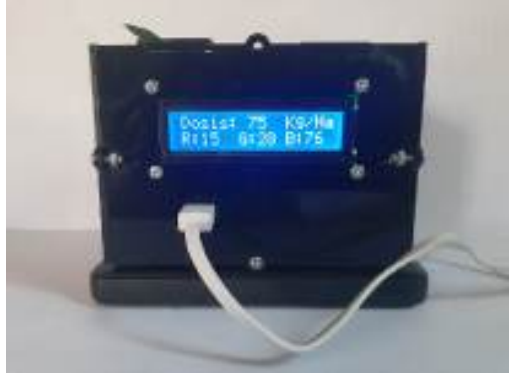

Gambar 16. Tampilan alat dosis pada LCD indikator 4

2. Pengujian pada sampel daun indikator BWD dengan alat E-BWD

Setelah melakukan proses scanning dan mengisi data pada form maka nilai dosis akan muncul $75 \mathrm{Kg} / \mathrm{Ha}$ sesuai nilai dosis yang telah di tetapkan oleh kementrian pertanian. Dan pengguna dapat menyimpannya dengan menekan tombol simpan.

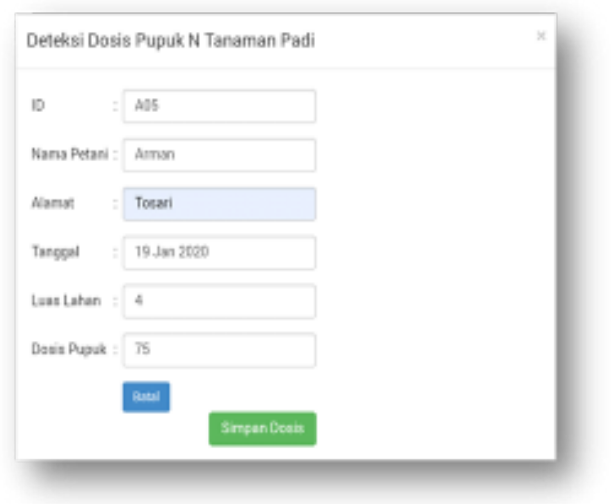

Gambar 17. Tampilan alat dosis pada LCD indikator 4

3. Pengujian pada sampel daun indikator 4 BWD dengan alat E-BWD

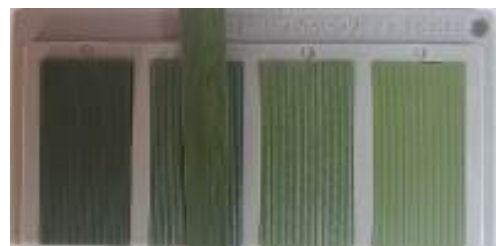

Gambar 18. Tampilan alat dosis pada LCD indikator 4

Gambar diatas menunjukkan berupa warna daun padi sesuai warna BWD dengan indikator nomor dua. Dan dosis BWD sama dengan dosis yang dikeluarkan oleh E-BWD yaitu $75 \mathrm{Kg} / \mathrm{Ha}$ 
Pengujian pada sampel daun indikator 5 BWD dengan alat E-BWD

1. Pengujian pada sampel daun indikator 5 BWD dengan alat E-BWD

Pada pengujian dengan daun padi yang mempunyai warna yang sama dengan warna indikator nomor 5 BWD menunjukkan hasil RGB dengan rata-rata diatas sesuai Indikator 5 Kalibrasi. Sebelumnya peneliti membuat range untuk membatasi nilai minimum dan nilai maksimal RGB. Nilai RGB itulah yang menjadi patokan dari berapa jumlah dosis yang akan keluar pada LCD maupun Website.

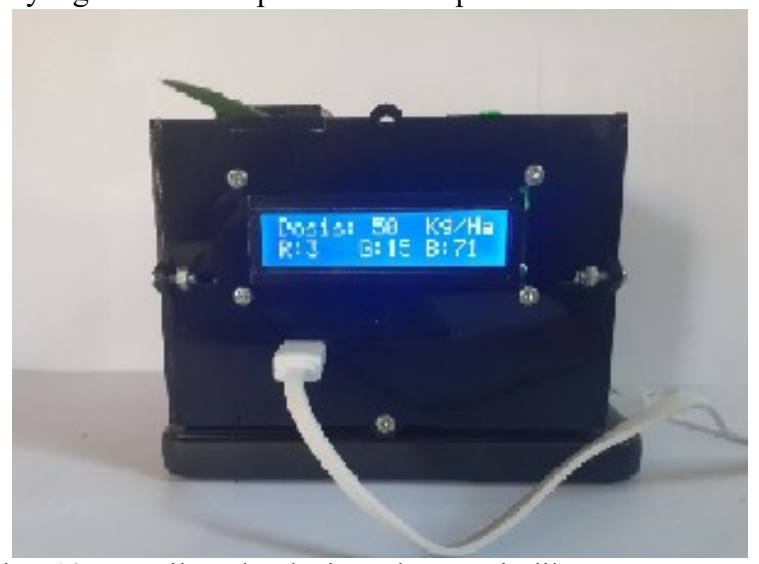

Gambar 19.Tampilan alat dosis pada LCD indikator 5

Dilihat pada gambar diatas menunjukkan nilai RGB dari rata-rata setelah lima kali melakukan proses scanning. Dari setiap melakukan proses scanning, alat akan menampilkan nilai RGB dari daun tersebut.

2. Pengujian pada sampel daun indikator 4 BWD dengan alat E-BWD

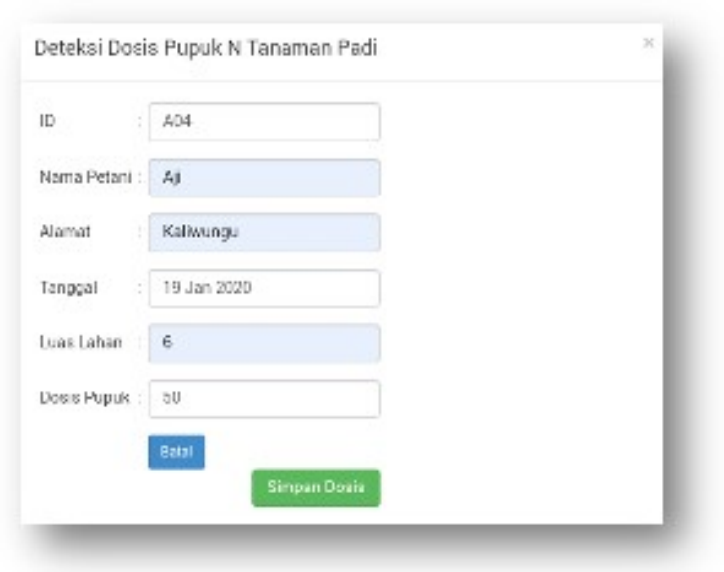

Gambar 20. Tampilan alat dosis pada LCD indikator 5

Setelah melakukan proses scanning dan mengisi data pada form maka nilai dosis akan muncul $50 \mathrm{Kg} / \mathrm{Ha}$ sesuai nilai dosis yang telah di tetapkan oleh kementrian pertanian. Dan pengguna dapat menyimpannya dengan menekan tombol simpan.

3. Pengujian pada sampel daun indikator 4 BWD dengan alat E-BWD

JURNAL ILMIAH ELEKTRONIKA DAN KOMPUTER Vol. 13, No. 1, Juli $2020: 87$ - 102 
Gambar diatas menunjukkan berupa warna daun padi sesuai warna BWD dengan indikator nomor dua. Dan dosis BWD sama dengan dosis yang dikeluarkan oleh E-BWD yaitu $50 \mathrm{Kg} / \mathrm{Ha}$

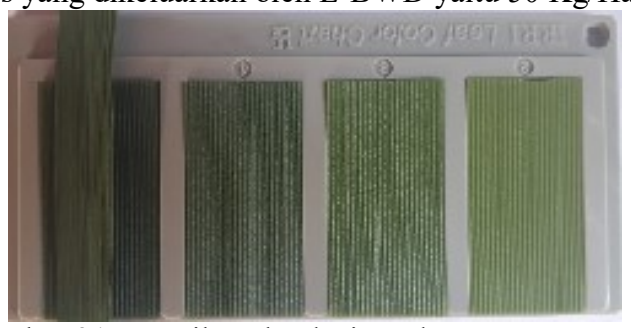

Gambar 21.Tampilan alat dosis pada LCD

Hasil pengujian sampel dengan 4 indikator sesuai Bagan Warna Daun (BWD) oleh alat E-BWD

Hasil pengujian pada 4 jenis warna padi sesuai indikator BWD yang telah direkomendasikan oleh Kementrian Pertanian Republik Indonesia

\section{Pengujian Sistem dan Pembahasan}

Tabel 4. Pengujian daun padi yang sesuai dengan indikator 2 BWD

\begin{tabular}{cccc}
\hline Sampel daun & Alat & $\begin{array}{c}\text { E- } \\
\text { BWD }\end{array}$ & BWD \\
\hline 1 & $\checkmark$ & $\checkmark$ & $\checkmark$ \\
2 & $\checkmark$ & $\checkmark$ & $\checkmark$ \\
3 & $\checkmark$ & $\checkmark$ & $\checkmark$ \\
4 & $\checkmark$ & $\checkmark$ & $\checkmark$ \\
5 & $\checkmark$ & $\checkmark$ & $\checkmark$ \\
Dosis & & $\mathbf{1 2 5}$ Kg/Ha \\
BWD & \multicolumn{4}{c}{ Sesuai } \\
\hline
\end{tabular}

Pada table 4 terlihat nilai dari daun yang di gunakan yg terbaca pada BWD, alat dan E-BWD sesuai pada dosis $125 \mathrm{~kg} / \mathrm{Ha}$ sehingga alat dapat membaca warna daun yg nilai nya sesuai

Tabel 5. Pengujian daun padi yang sesuai dengan indikator 3 BWD

\begin{tabular}{cccc}
\hline Sampel daun & Alat & $\begin{array}{c}\text { E- } \\
\text { BWD }\end{array}$ & BWD \\
\hline 1 & $\checkmark$ & $\checkmark$ & $\checkmark$ \\
2 & $\checkmark$ & $\checkmark$ & $\checkmark$ \\
3 & $\checkmark$ & $\checkmark$ & $\checkmark$ \\
4 & $\checkmark$ & $\checkmark$ & $\checkmark$ \\
5 & $\checkmark$ & $\checkmark$ & $\checkmark$ \\
Dosis & & $\mathbf{1 0 0 ~ K g / H a}$ & \\
BWD & & Sesuai \\
\hline
\end{tabular}

Pada table 5 terbaca nilai yang sesuai untuk dosis $100 \mathrm{Kg} / \mathrm{Ha}$, warna daun terbaca oleh alat dan BWD serta E-BWD bernilai sesuai sehingga alat dapat di katakan Valid.

Tabel 6.Pengujian daun padi yang sesuai dengan indikator 4 BWD

Rancang Bangun Sistem Informasi Penjualan Online Berbasis Webmobile 


\begin{tabular}{cccc}
\hline Sampel daun & Alat & $\begin{array}{c}\text { E- } \\
\text { BWD }\end{array}$ & BWD \\
\hline 1 & $\checkmark$ & $\checkmark$ & $\checkmark$ \\
2 & $\checkmark$ & $\checkmark$ & $\checkmark$ \\
3 & $\checkmark$ & $\checkmark$ & $\checkmark$ \\
4 & $\checkmark$ & $\checkmark$ & $\checkmark$ \\
5 & $\checkmark$ & $\checkmark$ & $\checkmark$ \\
Dosis & & $\mathbf{7 5}$ Kg/Ha & \\
BWD & & Sesuai
\end{tabular}

Pada gambar 6 nilai daun di ketahui sudah sesuai dengan bagan warna untuk dosis $75 \mathrm{Kg} / \mathrm{Ha}$ sehingg alat dapat di katakana benar membaca warna daun selain itu pembacaan antara BWD, Alat dan EBWD sesuai.

Tabel 7 Pengujian daun padi yang sesuai dengan indikator 5 BWD

\begin{tabular}{cccc}
\hline Sampel daun & Alat & $\begin{array}{c}\text { E- } \\
\text { BWD }\end{array}$ & BWD \\
\hline 1 & $\checkmark$ & $\checkmark$ & $\checkmark$ \\
2 & $\checkmark$ & $\checkmark$ & $\checkmark$ \\
3 & $\checkmark$ & $\checkmark$ & $\checkmark$ \\
4 & $\checkmark$ & $\checkmark$ & $\checkmark$ \\
5 & $\checkmark$ & $\checkmark$ & $\checkmark$ \\
Dosis & & $\mathbf{5 0 ~ K g / H a}$ & \\
BWD & & Sesuai &
\end{tabular}

Pada table 7 terlihat nilai daun untuk dosis $50 \mathrm{~kg} / \mathrm{Ha}$ sudah sesuai denga nilai pada alat, BWD dan E-BWD sehingga nilai sesuai.

Keterangan : Alat : perlengkapan mikrokontroler yang mendeteksi warna daun E-BWD : Aplikasi BWD online BWD : Bagan Warna Daun

Pada pengujian di setiap indikator dari 1-5 di ketahui alat yang di kembangkan mampu memdeteksi dan menghasil kan output yang sama dengan table BWD yang sudah ada, sehingga untuk pengamatan apakah warna daun yang cocok dapat di ketahui melalui sistem secara otomatis dan tidak perlu pengamatan yang mengandal kan intuisi petani dalam menentukan warna daun. Selain itu data setiap lokasi yang telah di beri pupuk dapat di ketahui berserta dosis nya sehingga data ini bisa di kembang kan untuk keperluan yang lain nya atau pun sebagai data pembanding .

Data aplikasi yang memuat lokasi, jumlah urea yang di berikan, tersimpan di database menyebabkan untuk ke depan nya bisa di perkirakan jumlah penggunaan pupuk urea yang bagus untuk luas lahan tertentu, data ini bisa di akses di mana saja karena berbasis internet .

\section{Kesimpulan}

Berdasarkan analisa dan hasil perancangan sistem ini, maka dapat disimpulkan sebagai berikut :

1. Penelitian yang penulis buat ialah tentang Sistem Penentuan Dosis Kebutuhan Pupuk Nitrogen Berdasar Warna Daun (BWD) Pada Tanaman Padi Dengan Sensor TCS 3200 Berbasis IOT. Sesuai dengan tujuan penelitian alat ini dapat merekomendasikan penentuan pemberian pupuk

JURNAL ILMIAH ELEKTRONIKA DAN KOMPUTER Vol. 13, No. 1, Juli $2020: 87$ - 102 
Nitrogen berdasar warna daun BWD yang dapat dilihat pada Gambar 5-Gambar 21 dapat dilihat secara realtime dan dapat diakses dimanapun menggunakan jaringan internet

2. Dalam pembuatan sistem yang baru dapat disimpulkan bahwa kelebihan alat ini sebagai berikut:

a. Alat dapat memberikan rekomendasi dosis pupuk Nitrogen sesuai Bagan Warna Daun (BWD).

b. Dapat digunakan dimanapun, asal terintregasi Internet

c. Dapat memberikan informasi mengenai dosis pupuk Nitrogen melalui website .

d. Dapat memberikan dosis anjuran kepada petani berdasar luas lahan mereka

\section{DAFTAR PUSTAKA}

[1] Y. Ambarita and D. Hariyono, "Aplikasi Pupuk NPK dan Urea Pada Padi (Oryza Sativa L.) Sistem Ratun,” J. Produksi Tanam., vol. 5, no. 7, pp. 1228-1234, 2017.

[2] L. Terhadap, K. Nitrogen, R. Laila, A. Abu, Z. Basri, and U. Made, "RESPON PERTUMBUHAN DAN HASIL TANAMAN PADI ( Oryza BAGAN WARNA DAUN Response of Growth and Yield of Rice ( Oryza sativa L.) Plant on the Need for Nitrogen Using Leaf Color Chart," Agroland, vol. 24, no. 2, pp. 119-127, 2017.

[3] A. S. Wahid, "Peningkatan Efisiensi Pupuk Nitrogen Pada Padi Sawah Dengan Metode Bagan Warna Daun," Litbang Pertan., vol. 22, no. 4, pp. 156-161, 2003.

[4] D. Danang, S. Suwardi, and I. A. Hidayat, "Mitigasi Bencana Banjir dengan Sistem Informasi Monitoring dan Peringatan Dini Bencana menggunakan Microcontroller Arduino Berbasis loT," Teknik, vol. 40, no. 1, p. 55, 2019.

[5] Q. Li, Y. Xiong, W. Yang, J. Han, and H. Liang, "Study on Color Analyzer based on the Multiplexing of TCS3200 Color Sensor and Microcontroller," Int. J. Hybrid Inf. Technol., vol. 7, no. 5, pp. 167-174, 2014.

[6] M. F. Wicaksono, "Implementasi Modul Wifi Nodemcu Esp8266 Untuk Smart Home," J. Tek. Komput. Unikom, vol. 6, no. 1, pp. 1-6, 2017.

[7] Y. Amri and M. A. Setiawan, "Improving Smart Home Concept with the Internet of Things Concept Using RaspberryPi and NodeMCU," IOP Conf. Ser. Mater. Sci. Eng., vol. 325, no. 1, 2018.

[8] K. A. Aka, "Integration Borg \& Gall (1983) and Lee \& Owen (2004) models as an alternative model of design-based research of interactive multimedia in elementary school," J. Phys. Conf. Ser., vol. 1318, no. 1, 2019.

[9] W. K. G. Assunção, S. R. Vergilio, and R. E. Lopez-Herrejon, "Automatic extraction of product line architecture and feature models from UML class diagram variants," Inf. Softw. Technol., vol. 117, no. October 2019, 2020.

[10] K. B. Kumar Sai, S. Mukherjee, and H. Parveen Sultana, "Low Cost loT Based Air Quality Monitoring Setup Using Arduino and MQ Series Sensors with Dataset Analysis," Procedia Comput. Sci., vol. 165, no. 2019, pp. 322-327, 2019.

[11] A. Juliano, A. H. Hendrawan, and R. Ritzkal, "Information System Prototyping of Strawberry Maturity Stages using Arduino Uno and TCS3200," J. Robot. Control, vol. 1, no. 3, pp. 86-91, 2020.

[12] L. Shkurti, X. Bajrami, E. Canhasi, B. Limani, S. Krrabaj, and A. Hulaj, "Development of ambient environmental monitoring system through wireless sensor network (WSN) using NodeMCU and 'WSN monitoring,'”' 20176 th Mediterr. Conf. Embed. Comput. MECO 2017 - Incl. ECYPS 2017, Proc., no. June, pp. 11-15, 2017. 
